\title{
Microgravity control of autophagy modulates osteoclastogenesis
}

\author{
Yuvaraj Sambandam ${ }^{\mathrm{a}}$, Molly T. Townsend ${ }^{\mathrm{a}}$, Jason J. Pierce ${ }^{\mathrm{a}}$, Cecilia M. Lipman ${ }^{\mathrm{a}}$, Azizul \\ Haque $^{b}$, Ted A. Bateman ${ }^{c}$, and Sakamuri V. Reddy ${ }^{a},{ }^{*}$ \\ aCharles P. Darby Children's Research Institute, Medical University of South Carolina, \\ Charleston, SC, USA \\ bDepartment of Microbiology \& Immunology, Medical University of South Carolina, Charleston, \\ SC, USA \\ 'Department of Biomedical Engineering, University of North Carolina, Chapel Hill, NC, USA
}

\section{Abstract}

Evidence indicates that astronauts experience significant bone loss during space mission. Recently, we used the NASA developed rotary cell culture system (RCCS) to simulate microgravity $(\mu \mathrm{Xg})$ conditions and demonstrated increased osteoclastogenesis in mouse bone marrow cultures. Autophagy is a cellular recycling process of nutrients. Therefore, we hypothesize that $\mu \mathrm{Xg}$ control of autophagy modulates osteoclastogenesis. Real-time PCR analysis of total RNA isolated from mouse bone marrow derived non-adherent cells subjected to modeled $\mu \mathrm{Xg}$ showed a significant increase in autophagic marker Atg5, LC3 and Atg16L mRNA expression compared to ground based control (Xg) cultures. Western blot analysis of total cell lysates identified an 8.0fold and 7.0-fold increase in the Atg5 and LC3-II expression, respectively. Confocal microscopy demonstrated an increased autophagosome formation in $\mu \mathrm{Xg}$ subjected RAW 264.7 preosteoclast cells. $\mathrm{RT}^{2}$ profiler PCR array screening for autophagy related genes identified that $\mu \mathrm{Xg}$ upregulates intracellular signaling molecules associated with autophagy, autophagosome components and inflammatory cytokines/growth factors which coregulate autophagy in RAW 264.7 preosteoclast cells. Autophagy inhibitor, 3-methyladenine (3-MA) treatment of mouse bone marrow derived non-adherent mononuclear cells showed a significant decrease in $\mu \mathrm{Xg}$ induced Atg5 and LC3 mRNA expression in the presence or absence of RANK ligand (RANKL) stimulation. Furthermore, RANKL treatment significantly increased (8-fold) p-CREB transcription factor levels under $\mu \mathrm{Xg}$ as compared to Xg cultures and 3-MA inhibited RANKL increased p-CREB expression in these cells. Also, 3-MA suppresses $\mu \mathrm{Xg}$ elevated osteoclast differentiation in mouse bone marrow cultures. Thus, our results suggest that $\mu \mathrm{Xg}$ induced autophagy plays an important role in enhanced osteoclast differentiation and could be a potential therapeutic target to prevent bone loss in astronauts during space flight missions.

(C) 2014 Elsevier Inc. All rights reserved

"Corresponding author at: Children's Research Institute Osteoclast Center, 96 Jonathan Lucas Street, CSB 428 MSC 608, Charleston, SC 29425, USA. Fax: +1 843792 7927. reddysv@musc.edu (S.V. Reddy).

The authors declare no conflict of interests. 


\section{Keywords}

Osteoclast; Autophagy; Microgravity; Rotary cell culture system (RCCS); NASA

\section{Introduction}

Space flight is a challenge for normal bone homeostasis in astronauts. Evidence is accumulating that unloading of the skeleton either due to space-flight or an altered gravitational environment results in a reduction of bone mineral density. Astronauts experience about $10-15 \%$ loss of bone mass in microgravity $(\mu \mathrm{Xg})[1,2]$ and the morphological changes resemble bones of osteoporotic patients [3,4]. In long-term space missions, astronauts can lose bone mass in the proximal femur in one month, as seen in postmenopausal women on earth in one year [5]. Therefore, high bone turnover in $\mu \mathrm{Xg}$ conditions may lead to bone loss and fracture risk in astronauts. Although astronauts' daily tasks include nutritional supplementation and regimented exercise for skeletal health, irreversible bone loss has serious implications for long-term inhabitants of the space station and space exploration.

The osteoclast (OCL) is the bone resorbing cell and M-CSF is required for proliferation and survival of OCL precursors. The TNF family member, receptor activator for nuclear factor $\kappa \mathrm{B}$ ligand (RANKL), is critical for OCL precursor differentiation to form multinucleated OCL in the bone microenvironment. RANKL interaction with RANK receptor expressed on OCL progenitor cells results in activation of various signaling cascades during OCL differentiation and bone resorption [6]. In-flight studies conducted during the FOTON-3 mission revealed that OCLs and their precursors are direct targets for $\mu \mathrm{Xg}$ and mechanical force could be responsible for modulating gene expression associated with OCL differentiation/activity [7]. Further, $\mu \mathrm{Xg}$ is capable of stimulating OCL differentiation by regulating osteoblast secretion of RANKL and osteoprotegerin (OPG) [8]. Also, it has been shown that bone forming activity of osteoblast cells decreases under $\mu \mathrm{Xg}$ conditions $[9,10]$. It has been reported that $\mu \mathrm{Xg}$ reduces osteoblast life span and increases OCL activity which contributes to bone loss associated with weightlessness [11]. Furthermore, uncoupling of bone formation and resorption favors bone loss in cosmonauts during and after 180 days of space flight [12]. Similarly, intact limb bones of newts flown on board the biosatellite Cosmos-2229 revealed OCL activation and resorption on the endosteal surface [13]. It has been shown that skeletal unloading in mice diminishes bone quality in the tibia and fibula which leads to an increase in bone fracture risk [14]. Additionally, skeletal unloading in mice, bone mass is reduced due to elevated RANKL expression and osteoclastogenesis [15]. Also, RANKL expressed in osteocytes is responsible for bone loss associated with skeletal unloading in mice [16]. Similarly, it was demonstrated that isolated fetal mouse long bones under near weightlessness conditions show decreased mineralization and increased calcium release [9]. In addition, complicities of excess calcium mobilization from bones cause kidney stone formation.

Recently, we used the NASA developed ground based rotary cell culture system (RCCS) to simulate microgravity $(\mu \mathrm{Xg})$ conditions for mouse bone marrow cultures and showed 
increased osteoclastogenesis. We also determined the gene expression profiling during OCL differentiation of RAW 264.7 cells subjected to modeled $\mu \mathrm{Xg}$ by Agilent microarray analysis. We thus identified that $\mu \mathrm{Xg}$ significantly increases expression of critical molecules such as cytokines/growth factors, proteases and signaling proteins, which may enhance OCL differentiation/ function [17]. However, the mechanisms of $\mu \mathrm{Xg}$ induced bone loss and the rational approaches to prevent fracture risk associated with prolonged weightlessness conditions are yet to be established.

Autophagy is a cellular, self-consumption process characterized by sequestration of bulk cytoplasm, long-lived proteins and organelle degradation that is critical for cellular homeostasis [18]. Autophagy has pleiotropic functions that are involved in cell survival, nutrient supply under starvation, defense against pathogens and antigen presentation [19]. In metabolic stress, endoplasmic reticulum (ER) stress, hypoxia and pathological conditions, autophagy is greatly increased, allowing the cell to degrade defected proteins and organelles to recycle macromolecular precursors, such as amino acids, fatty acids, and nucleotides [20]. Beclin-1 and autophagy proteins (Atgs) are involved in initiation and formation of autophagosome. It has been reported that autophagy proteins regulate the secretory lysosomes that are directed to fuse with the OCL ruffled border [21]. Similarly, interruption in the autophagic process has been shown to delocalize cathepsin $\mathrm{K}$ and reduce OCL bone resorption activity. Further, Rab7, which is required for OCL function, localizes to the ruffled border in an Atg5 dependent manner and participates in polarized secretion of lysosomal contents into the extracellular space by directing lysosomes to fuse with the plasma membrane [22]. Recently, it has been identified that autophagy is a pivotal regulator of hypoxia-induced OCL differentiation through the HIF-1a/ BNIP3 signaling pathway and that inhibition of oxidative stress decreased autophagy. Furthermore, autophagy inhibition by 3'-methyladenine (3-MA) LY294002, wortmannin or knock-down of Beclin-1/Atg 7 decreased OCL marker gene expression [23]. However, $\mu \mathrm{Xg}$ control of autophagy and OCL differentiation is unknown.

\section{Materials and methods}

\section{Modeled microgravity $(\mu \mathrm{Xg})$ and cell culture}

The Rotating Wall Vessel Bioreactor (RWV) (Synthecon Inc., Texas) is a horizontally oriented rotary cell culture (RCC) system. A silicone membrane is located on the central axis of a rotation chamber to diffuse gases necessary for cell growth without creating turbulence. The solid-body rotation of the chamber causes a reduction of the medium's shear stress [24]. The vessel was filled with a-minimum essential medium (MEM) free of bubbles and rotated at a constant speed of $16 \mathrm{rpm}$ for $24 \mathrm{~h}$ to simulate microgravity $(0.008 \mathrm{Xg})$, termed modeled microgravity $(\mu \mathrm{Xg})$. Ground based control or static gravity $(1 \mathrm{Xg})$ is termed $\mathrm{Xg}$ [25]. Bone marrow was flushed from long bones of 6-8 week-old mice (C57BL/6) using a-MEM. Cells were pelleted at $1500 \mathrm{rpm}$ for $7 \mathrm{~min}$ at room temperature and plated in aMEM with $10 \%$ fetal bovine serum (FBS) supplemented with M-CSF (10 ng/ml) and cultured overnight. Non-adherent mouse bone marrow cells $\left(1.5 \times 10^{6} / \mathrm{ml}\right)$ or RAW 264.7 cells $\left(1 \times 10^{4} / \mathrm{ml}\right)$ subjected to modeled $\mu \mathrm{Xg}$ in RCCS for $24 \mathrm{~h}$ were cultured in a 24 well plate for 7 or 5 days, respectively, in the presence of M-CSF (10 ng/ml) and RANKL (75 
ng/ml) (R\&D Systems Inc., Minneapolis, MN). Cells were fixed with 2\% glutaraldehyde in phosphate buffered saline (PBS) and stained for tartrate-resistant acid phosphatase (TRAP) activity using a histochemical kit (Sigma Chemical Co., St. Louis, MO). TRAP positive multinucleated cells (MNC) containing three or more nuclei were scored as osteoclasts (OCLs) under a microscope as described [26]. All procedures involving animal use were approved by the Institutional Animal Care and Use Committee of the Medical University of South Carolina.

\section{Real-time RT-PCR}

Total RNA was isolated from ground based control $(\mathrm{Xg})$ and $\mu \mathrm{Xg}$ subjected mouse bone marrow derived non-adherent cells treated with or without RANKL $(75 \mathrm{ng} / \mathrm{ml})$ and M-CSF (10 ng/ml) for $24 \mathrm{~h}$ using RNAzol reagent (Biotecx Labs, Houston, TX). The reverse transcription reaction was performed using iScript reverse transcriptase in a $20 \mu \mathrm{l}$ reaction volume containing total RNA ( $2 \mu \mathrm{g}), 4 \mu \mathrm{l}$ amino acid buffer and nuclease-free water at $42{ }^{\circ} \mathrm{C}$ for $15 \mathrm{~min}$ followed by $99^{\circ} \mathrm{C}$ for $5 \mathrm{~min}$ and $4{ }^{\circ} \mathrm{C}$ for $5 \mathrm{~min}$. Real-time PCR was performed using IQ ${ }^{\mathrm{TM}}$ SYBR Green Supermix in an iCycler (iCycler iQ Single-color Real-Time PCR detection system; Bio-Rad, Hercules, CA). The forward and reverse primer sequences used to amplify the selected genes are listed as follows: Atg5 sense: 5'-CTG TCA AGT GCC TGC TGC T- $3^{\prime}$, antisense: $5^{\prime}$-GTG AGC CTC AAC CGC ATC- ${ }^{\prime}$; LC3 sense: $5^{\prime}$-CCA CCA AGA TCC CAG TGA TT-3', antisense: 5'-CGC CGT CTG ATT ATC TTG ATG-3'; Atg16L sense: $5^{\prime}$-ACA TGA TGG TGC GTG GAA T-3', antisense: $5^{\prime}$-TTG TCC TTC TGC TGC ATT TG-3'; and $\beta$-actin sense: $5^{\prime}$-CCA CAC CTT CCT ACA ATG AGC-3', antisense: $5^{\prime}$-TAG AGG AAG ACG TAG GAC AG-3'. Thermal cycling parameters were $94{ }^{\circ} \mathrm{C}$ for 3 min, followed by 40 cycles of amplifications at $94{ }^{\circ} \mathrm{C}$ for $30 \mathrm{~s}, 60^{\circ} \mathrm{C}$ for $1 \mathrm{~min}, 72{ }^{\circ} \mathrm{C}$ for 1 min, and $72{ }^{\circ} \mathrm{C}$ for $5 \mathrm{~min}$ as the final elongation step. Relative levels of mRNA expression were normalized in all analyzed samples with respect to levels of $\beta$-actin amplification as described [27].

\section{$\mathrm{RT}^{2}$ profiler PCR array screening}

RAW 264.7 cells $\left(1 \times 10^{4}\right.$ cells $\left./ \mathrm{ml}\right)$ were subjected to modeled $\mu \mathrm{Xg}$ or ground based control (Xg) cultures for $24 \mathrm{~h}$ and total RNA was isolated using RNAzol reagent. Reverse transcription reaction was done using poly-dT primer and Moloney murine leukemia virus reverse transcriptase as described above. Real-time PCR was performed using $2 \times \mathrm{RT}$ qPCR Master Mix to screen the RT ${ }^{2}$ Profiler PCR Array System (PAMM-084A) in a 96-well plate to quantify expression levels of 84 autophagy related genes. Thermal cycling parameters were $95^{\circ} \mathrm{C}$ for $10 \mathrm{~min}$, followed by 40 cycles of amplifications at $95{ }^{\circ} \mathrm{C}$ for $15 \mathrm{~s}, 55^{\circ} \mathrm{C}$ for $30 \mathrm{~s}, 72^{\circ} \mathrm{C}$ for $30 \mathrm{~s}$, and $72{ }^{\circ} \mathrm{C}$ for $5 \mathrm{~min}$ as the final elongation step. Relative levels of mRNA expression were normalized in all the samples with expression levels of housekeeping genes (GUSB, HPRT, HSP90AB1, GAPDH and $\beta$-actin) in triplicate studies, and data analysis was done using the Web portal.

\section{Western blot analysis}

Mouse bone marrow derived non-adherent cells cultured with a-MEM containing 10\% FBS were subjected to $\mu \mathrm{Xg}$. Cells were stimulated with or without RANKL $(75 \mathrm{ng} / \mathrm{ml})$ and MCSF (10 ng/ml) for $24 \mathrm{~h}$ and total cell lysates were prepared in a buffer containing $20 \mathrm{mM}$ 
Tris- $\mathrm{HCl}$ at $\mathrm{pH} 7.4,1 \%$ Triton $\mathrm{X}-100,1 \mathrm{mM}$ EDTA, $1.5 \mathrm{mM} \mathrm{MgCl}_{2}, 10 \%$ glycerol, 150 $\mathrm{mM} \mathrm{NaCl}, 0.1 \mathrm{mM} \mathrm{Na}_{3} \mathrm{VO}_{4}$ and $1 \times$ protease inhibitor cocktail. The protein content of the samples was measured using the BCA protein assay reagent (Pierce, Rockford, IL). Protein $(100 \mu \mathrm{g})$ samples were then subjected to SDS-PAGE using 12\% Tris-HCl gels and blot transferred on to a PVDF membrane, immunoblotted with antibody against Atg5, LC3-II, PLC $\gamma 2$, p-CREB, CREB and $\beta$-actin. The bands were detected using the enhanced chemiluminescence detection system (Pierce, Rockford, IL) and band intensity was quantified by densitometric analysis using the NIH ImageJ Program.

\section{Confocal microscopy}

RAW 264.7 cells were exposed to $\mu \mathrm{Xg}$ and normal gravity $(\mathrm{Xg})$ conditions in parallel for 24 $\mathrm{h}$ and then cultured $\left(1 \times 10^{3} /\right.$ well) in Lab-Tek 4-well chamber slides (Nunc Inc., Rochester, NY) with RANKL ( $75 \mathrm{ng} / \mathrm{ml})$ and M-CSF $(10 \mathrm{ng} / \mathrm{ml})$ for $24 \mathrm{~h}$. Cells were fixed with $4 \%$ paraformaldehyde in PBS for $10 \mathrm{~min}$ at room temperature, permeabilized with $0.1 \%$ Triton X-100 for $10 \mathrm{~min}$ and blocked for $1 \mathrm{~h}$ with PBS containing 2\% horse serum at room temperature. Cells were incubated with LC3-II primary antibody for $3 \mathrm{~h}$ and treated with Alexa 488-conjugated anti-rabbit IgG in PBS containing 2\% horse serum for $1 \mathrm{~h}$ at room temperature. Autophagosome formation was visualized by confocal microscopy (LSM 510; Carl Zeiss, Inc., Thornwood, NY).

\section{Statistical analysis}

Results are presented as mean \pm SD for three independent experiments and compared by Student's $t$-test. Values were considered significant at $\mathrm{P}<0.05$.

\section{Results}

\section{Microgravity $(\mu \mathrm{Xg})$ induces autophagy in preosteoclast cells}

Previously, we showed that modeled $\mu \mathrm{Xg}$ increases OCL formation in mouse bone marrow cultures [17]. However, the molecular mechanisms underlying $\mu \mathrm{Xg}$ modulation of OCL differentiation are unclear. Recent studies implicated autophagy/autophagy proteins as playing an important role in enhanced osteoclastogenesis $[21,23,28]$. We therefore examined $\mu \mathrm{Xg}$ modulation of autophagy markers in preosteoclast cells. Mouse bone marrow derived non-adherent cells were subjected to modeled $\mu \mathrm{Xg}$ in RCCS for $24 \mathrm{~h}$ as described in the Materials and methods section. Real-time RT-PCR analysis of total RNA isolated from these cells demonstrated high levels of Atg5 (20-fold), LC3 (35-fold) and Atg16L (2.8-fold) mRNA expression without RANKL treatment when compared to ground based control $(\mathrm{Xg})$ cultures without RANKL stimulation (Fig. 1). Western blot analysis of total cell lysates obtained from the $\mu \mathrm{Xg}$ subjected preosteoclast cells without RANKL stimulation demonstrated an 8.0-fold and 7.0-fold increase in the Atg5 and LC3-II expression, respectively (Fig. 2A). Autophagy involves conversion of the cytoplasmic microtubuleassociated protein 1 light chain 3 (LC3-I) into the membrane form of LC3-II during autophagosome formation [29,30]. Therefore, we performed confocal microscopy analysis for LC3-II expression in preosteoclast cells, and identified an abundant autophagosome formation in RAW 264.7 cells cultured under $\mu \mathrm{Xg}$ in the absence of RANKL stimuli compared to ground based control (Xg) cultures (Fig. 2B). 


\section{$\mathrm{RT}^{2}$ Profiler PCR array screening for $\mu \mathrm{Xg}$ regulated autophagy related genes}

We next examined $\mu \mathrm{Xg}$ regulation of autophagy related gene expression using the $\mathrm{RT}^{2}$ Profiler PCR array consisting of 84 different genes. We thus identified $\mu \mathrm{Xg}$ upregulated mRNA expression of GAA, Trp53, Prkaa1, Rps6kb1, intracellular signaling molecules associated with autophagy, autophagosome components such as Atg16L, Atg9b, Irgm1, and inflammatory cytokines/growth factors such as Tnfsf10, IFN- $\gamma$ and IGF1 which coregulate autophagy in preosteoclast cells (Fig. 3A). Calcium signaling has been shown to directly modulate autophagy [31,32]. Since PLC $\gamma 2$ is involved in the regulation of intracellular $\mathrm{Ca}^{2+}$ level $[33,34]$, we further examined $\mu \mathrm{Xg}$ regulation of PLC $\gamma 2$ expression in mouse bone marrow derived non-adherent cells. Western blot analysis of total cell lysates obtained from ground based control $(\mathrm{Xg})$ and $\mu \mathrm{Xg}$ subjected preosteoclast cells revealed that $\mu \mathrm{Xg}$ significantly increased the PLC $\gamma 2$ expression with or without RANKL stimulation compared to ground based control (Xg) cultures (Fig. 3B). $\beta$-actin expression served as control. These results indicate that $\mu \mathrm{Xg}$ control of PLC $\gamma 2 /$ calcium signaling modulates autophagy in preosteoclast cells.

\section{Functional role of autophagy in $\mu \mathrm{Xg}$ induced $\mathrm{OCL}$ differentiation}

To determine the functional role of autophagy in OCL differentiation, mouse bone marrow derived non-adherent cells were subjected to $\mu \mathrm{Xg}$ for $24 \mathrm{~h}$ and cultured with or without RANKL and autophagy inhibitor (3-MA). As shown in Fig. 4A, real-time RT-PCR analysis of total RNA isolated from these cells demonstrated that 3-MA significantly down-regulates $\mu \mathrm{Xg}$ induced autophagosome markers, Atg5 and LC3 mRNA expression. We also identify that $\mu \mathrm{Xg}$ upregulated cathepsin $\mathrm{K}$ mRNA expression compared to ground based control $(\mathrm{Xg})$ conditions and 3-MA treatment ( $24 \mathrm{~h}$ ) of preosteoclast cells inhibits $\mu \mathrm{Xg}$ elevated cathepsin K mRNA expression (Fig. 4B). Furthermore, RANKL treatment significantly increased (8fold) phosphorylation of cAMP response element (CRE)-binding protein (p-CREB), a critical transcription factor for osteoclast (OCL) differentiation under $\mu \mathrm{Xg}$ as compared to $\mathrm{Xg}$ conditions. 3-MA markedly suppressed RANKL induced $\mathrm{p}$-CREB expression under $\mu \mathrm{Xg}$ and $\mathrm{Xg}$ conditions (Figs. 4C\&D). Nevertheless, 3-MA treatment did not affect the viability of cells (data not shown). To determine the effect of autophagy on $\mu \mathrm{Xg}$ enhanced OCL differentiation in vitro, mouse bone marrow derived non-adherent cells subjected to $\mu \mathrm{Xg}$ or control Xg were stimulated with M-CSF, RANKL with or without 3-MA for 7 days to form multinucleated osteoclasts. We identified that 3-MA inhibits OCL differentiation in Xg conditions. Interestingly, 3-MA treatment resulted in suppression of $\mu \mathrm{Xg}$ elevated OCL differentiation in mouse bone marrow cultures (Fig. 5).

\section{Discussion}

Space flight alters normal bone homeostasis and causes increased bone resorption in astronauts. Studies conducted during space flight indicated that $\mu \mathrm{Xg}$ directly regulates osteoclastogenesis [7]. In previous studies, we have shown that $\mu \mathrm{Xg}$ simulation using a RCCS system increased osteoclastogenesis in bone marrow cultures [17]. This study further identified that $\mu \mathrm{Xg}$ significantly increased autophagic marker Atg5 and LC3-II expression as well as autophagosome formation in preoteoclast cells. Therefore, since autophagy is a cellular recycling process of nutrients for survival and function it could enhance OCL 
formation. Recently, it has been shown that autophagy is activated by the pro-inflammatory cytokine TNF-a associated with inflammatory bone loss [35]. In this study, PCR array analysis identified that $\mu \mathrm{Xg}$ upregulates inflammatory cytokines such as Tnfsf10 in preosteoclast cells. It is possible that $\mu \mathrm{Xg}$ upregulation of inflammatory cytokines may elevate autophagic activity and osteoclast (OCL) formation. Autophagy proteins such as Atg5 have been shown to regulate the secretory component of osteoclastic bone resorption [21]. Our results have shown that autophagy inhibitor (3-MA) significantly decreased $\mu \mathrm{Xg}$ induced cathepsin $\mathrm{K}$ expression in mouse bone marrow derived preosteoclast cells suggesting that autophagy inhibition may diminish OCL bone resorption activity under $\mu \mathrm{Xg}$ conditions. p62/SQSTM1 interaction with autophagy-linked WDFY3 protein has been shown to play a functional role in osteoclasts [36]. Recently, it has been identified that aquaporin-9 knock-out mice attenuated bone loss and inhibited OCL formation in a hindlimb suspension mouse model [37]. Therefore, $\mu \mathrm{Xg}$ may regulate autophagy in osteoclasts through complex molecular signaling mechanisms. Elevated $\mathrm{Ca}^{2+}$ oscillations modulate the CaMK-CREB pathway during OCL differentiation [17]. The CaMK-CREB pathway regulates the expression of OCL specific genes in cooperation with NFATc1 [38]. However, we previously found no significant change in the levels of NFATc1 expression, but rather increased levels of c-Jun, MITF, CREB transcription factors and cytosolic calcium levels in preosteoclast cells under $\mu \mathrm{Xg}$ conditions [17]. It has been reported that calcium signaling directly stimulates autophagy [31,32] and PLC $\gamma 2$ is involved in the regulation of intracellular $\mathrm{Ca}^{2+}$ level [33]. It has also been shown that space flight increases calcium release from bone [39]. Our findings that microgravity conditions increase PLC $\gamma 2$ expression suggest that the PLC $\gamma 2 /$ calcium signaling pathway modulates autophagy during OCL differentiation. CREB is activated by $\mathrm{Ca}^{2+} /$ calmodulin-dependent kinase (CaMK) IV and is crucial for OCL differentiation and function [38,40]. We showed elevated levels of pCREB in preosteoclast cells subjected to $\mu \mathrm{Xg}$ compared to normal gravity $(\mathrm{Xg})$ conditions [17]. Therefore, 3-MA inhibition of CREB activation under $\mu \mathrm{Xg}$ conditions suggests that suppression of autophagy could negatively regulate gene expression essential for OCL activation. Accordingly, we have demonstrated that autophagy inhibitor (3-MA) inhibits $\mu \mathrm{Xg}$ elevated OCL differentiation. Genetic and functional studies have implicated that autophagy is involved in bone cell function under normal and pathologic conditions [41]. In this study, we showed that 3-MA also inhibits OCL formation under Xg conditions which suggests that autophagy may play a role in bone loss associated with other skeletal disorders such as Paget's disease. It has been shown that autophagic protein, Atg5 gene deletion protects against experimental postmenopausal osteoporosis [21]. Also, autophagy inhibitor treatment recapitulated deficiency of FIP200, an essential component of autophagy which resulted in osteopenia in mice [42]. More recently, it has been reported that suppression of autophagy in osteocytes contributes to the low bone mass associated with aging [43]. Longterm space flight is also challenged by other factors such as radiation. Irradiated mice subjected to mechanical unloading via hind-limb suspension demonstrated bone loss $[44,45]$. Irradiation has also been shown to induce autophagy in human bone marrow mesenchymal stem cells [46]. Thus, our results suggest that $\mu \mathrm{Xg}$ induced autophagy enhances osteoclast differentiation and could be a potential therapeutic target to prevent bone loss in astronauts during space flight missions. 


\section{Acknowledgments}

This work is supported by South Carolina EPSCoR Consortium grant (Dr. Reddy).

\section{References}

1. Carmeliet G, Bouillon R. The effect of microgravity on morphology and gene expression of osteoblasts in vitro. FASEB J. 1999; 13(Suppl):S129-34. [PubMed: 10352154]

2. Sibonga JD. Spaceflight-induced bone loss: is there an osteoporosis risk? Curr Osteoporos Rep. 2013; 11:92-8. [PubMed: 23564190]

3. Garber MA, McDowell DL, Hutton WC. Bone loss during simulated weightlessness: a biomechanical and mineralization study in the rat model. Aviat Space Environ Med. 2000; 71:58692. [PubMed: 10870817]

4. Lang TF, Leblanc AD, Evans HJ, Lu Y. Adaptation of the proximal femur to skeletal reloading after long-duration spaceflight. J Bone Miner Res. 2006; 21:1224-30. [PubMed: 16869720]

5. Cavanagh PR, Licata AA, Rice AJ. Exercise and pharmacological countermeasures for bone loss during long-duration space flight. Gravit Space Biol Bull. 2005; 18:39-58. [PubMed: 16038092]

6. Reddy SV. Regulatory mechanisms operative in osteoclasts. Crit Rev Eukaryot Gene Expr. 2004; 14:255-70. [PubMed: 15663356]

7. Tamma R, Colaianni G, Camerino C, Di Benedetto A, Greco G, Strippoli M, et al. Microgravity during spaceflight directly affects in vitro osteoclastogenesis and bone resorption. FASEB J. 2009; 23:2549-54. [PubMed: 19329761]

8. Kanematsu M, Yoshimura K, Takaoki M, Sato A. Vector-averaged gravity regulates gene expression of receptor activator of NF-kappaB (RANK) ligand and osteoprotegerin in bone marrow stromal cells via cyclic AMP/protein kinase A pathway. Bone. 2002; 30:553-8. [PubMed: 11934645]

9. Van Loon JJ, Bervoets DJ, Burger EH, Dieudonne SC, Hagen JW, Semeins CM, et al. Decreased mineralization and increased calcium release in isolated fetal mouse long bones under near weightlessness. J Bone Miner Res. 1995; 10:550-7. [PubMed: 7610925]

10. Hughes-Fulford M, Lewis ML. Effects of microgravity on osteoblast growth activation. Exp Cell Res. 1996; 224:103-9. [PubMed: 8612673]

11. Rucci N, Migliaccio S, Zani BM, Taranta A, Teti A. Characterization of the osteoblast-like cell phenotype under microgravity conditions in the NASA-approved Rotating Wall Vessel bioreactor (RWV). J Cell Biochem. 2002; 85:167-79. [PubMed: 11891860]

12. Caillot-Augusseau A, Lafage-Proust MH, Soler C, Pernod J, Dubois F, Alexandre C. Bone formation and resorption biological markers in cosmonauts during and after a 180-day space flight (Euromir 95). Clin Chem. 1998; 44:578-85. [PubMed: 9510865]

13. Berezovska OP, Rodionova NV, Grigoryan EN, Mitashov VI. Changes in the numbers of osteoclasts in newts under conditions of microgravity. Adv Space Res. 1998; 21:1059-63. [PubMed: 11541351]

14. Ko CY, Seo DH, Kim HS. Deterioration of bone quality in the tibia and fibula in growing mice during skeletal unloading: gender-related differences. J Biomech Eng. 2011; 133:111003. [PubMed: 22168735]

15. Wang Y, Liu W, Masuyama R, Fukuyama R, Ito M, Zhang Q, et al. Pyruvate dehydrogenase kinase 4 induces bone loss at unloading by promoting osteoclastogenesis. Bone. 2012; 50:409-19. [PubMed: 21803180]

16. Xiong J, Onal M, Jilka RL, Weinstein RS, Manolagas SC, O’Brien CA. Matrix-embedded cells control osteoclast formation. Nat Med. 2011; 17:1235-41. [PubMed: 21909103]

17. Sambandam Y, Blanchard JJ, Daughtridge G, Kolb RJ, Shanmugarajan S, Pandruvada SN, et al. Microarray profile of gene expression during osteoclast differentiation in modelled microgravity. J Cell Biochem. 2010; 111:1179-87. [PubMed: 20717918]

18. Xie Z, Klionsky DJ. Autophagosome formation: core machinery and adaptations. Nat Cell Biol. 2007; 9:1102-9. [PubMed: 17909521] 
19. Fleming A, Noda T, Yoshimori T, Rubinsztein DC. Chemical modulators of autophagy as biological probes and potential therapeutics. Nat Chem Biol. 2011; 7:9-17. [PubMed: 21164513]

20. Hippert MM, O'Toole PS, Thorburn A. Autophagy in cancer: good, bad, or both? Cancer Res. 2006; 66:9349-51. [PubMed: 17018585]

21. DeSelm CJ, Miller BC, Zou W, Beatty WL, van Meel E, Takahata Y, et al. Autophagy proteins regulate the secretory component of osteoclastic bone resorption. Dev Cell. 2011; 21:966-74. [PubMed: 22055344]

22. Gelman A, Elazar Z. Autophagic factors cut to the bone. Dev Cell. 2011; 21:808-10. [PubMed: 22075143]

23. Wang K, Niu J, Kim H, Kolattukudy PE. Osteoclast precursor differentiation by MCPIP via oxidative stress, endoplasmic reticulum stress, and autophagy. J Mol Cell Biol. 2011; 3:360-8. [PubMed: 21990425]

24. Zayzafoon M, Gathings WE, McDonald JM. Modeled microgravity inhibits osteogenic differentiation of human mesenchymal stem cells and increases adipogenesis. Endocrinology. 2004; 145:2421-32. [PubMed: 14749352]

25. Hughes JH, Long JP. Simulated microgravity impairs respiratory burst activity in human promyelocytic cells. In Vitro Cell Dev Biol Anim. 2001; 37:209-15. [PubMed: 11409685]

26. Shanmugarajan S, Irie K, Musselwhite C, Key LL Jr, Ries WL, Reddy SV. Transgenic mice with OIP-1/hSca overexpression targeted to the osteoclast lineage develop an osteopetrosis bone phenotype. J Pathol. 2007; 213:420-8. [PubMed: 17940999]

27. Yuvaraj S, Griffin AC, Sundaram K, Kirkwood KL, Norris JS, Reddy SV. A novel function of CXCL13 to stimulate RANK ligand expression in oral squamous cell carcinoma cells. Mol Cancer Res. 2009; 7:1399-407. [PubMed: 19671684]

28. Zhao Y, Chen G, Zhang W, Xu N, Zhu JY, Jia J, et al. Autophagy regulates hypoxia-induced osteoclastogenesis through the HIF-1alpha/BNIP3 signaling pathway. J Cell Physiol. 2012; 227:639-48. [PubMed: 21465467]

29. Kabeya Y, Mizushima N, Ueno T, Yamamoto A, Kirisako T, Noda T, et al. LC3, a mammalian homologue of yeast Apg8p, is localized in autophagosome membranes after processing. EMBO J. 2000; 19:5720-8. [PubMed: 11060023]

30. Fujita N, Itoh T, Omori H, Fukuda M, Noda T, Yoshimori T. The Atg16L complex specifies the site of LC3 lipidation for membrane biogenesis in autophagy. Mol Biol Cell. 2008; 19:2092-100. [PubMed: 18321988]

31. Hoyer-Hansen M, Bastholm L, Szyniarowski P, Campanella M, Szabadkai G, Farkas T, et al. Control of macroautophagy by calcium, calmodulin-dependent kinase kinase-beta, and Bcl-2. Mol Cell. 2007; 25:193-205. [PubMed: 17244528]

32. Gao W, Ding WX, Stolz DB, Yin XM. Induction of macroautophagy by exogenously introduced calcium. Autophagy. 2008; 4:754-61. [PubMed: 18560273]

33. Patterson RL, van Rossum DB, Ford DL, Hurt KJ, Bae SS, Suh PG, et al. Phospholipase C-gamma is required for agonist-induced Ca2+ entry. Cell. 2002; 111:529-41. [PubMed: 12437926]

34. Patterson RL, van Rossum DB, Nikolaidis N, Gill DL, Snyder SH. Phospholipase C-gamma: diverse roles in receptor-mediated calcium signaling. Trends Biochem Sci. 2005; 30:688-97. [PubMed: 16260143]

35. Lin NY, Stefanica A, Distler JH. Autophagy: A key pathway of TNF-induced inflammatory bone loss. Autophagy. 2013:9.

36. Hocking LJ, Mellis DJ, McCabe PS, Helfrich MH, Rogers MJ. Functional interaction between sequestosome-1/p62 and autophagy-linked FYVE-containing protein WDFY3 in human osteoclasts. Biochem Biophys Res Commun. 2010; 402:543-8. [PubMed: 20971078]

37. Bu G, Shuang F, Wu Y, Ren D, Hou S. AQP9: a novel target for bone loss induced by microgravity. Biochem Biophys Res Commun. 2012; 419:774-8. [PubMed: 22390930]

38. Sato K, Suematsu A, Nakashima T, Takemoto-Kimura S, Aoki K, Morishita Y, et al. Regulation of osteoclast differentiation and function by the CaMK-CREB pathway. Nat Med. 2006; 12:1410-6. [PubMed: 17128269] 
39. Smith SM, McCoy T, Gazda D, Morgan JL, Heer M, Zwart SR. Space flight calcium: implications for astronaut health, spacecraft operations, and Earth. Nutrients. 2012; 4:2047-68. [PubMed: 23250146]

40. Soderling TR, Stull JT. Structure and regulation of calcium/calmodulin-dependent protein kinases. Chem Rev. 2001; 101:2341-52. [PubMed: 11749376]

41. Hocking LJ, Whitehouse C, Helfrich MH. Autophagy: a new player in skeletal maintenance? J Bone Miner Res. 2012; 27:1439-47. [PubMed: 22706899]

42. Liu F, Fang F, Yuan H, Yang D, Chen Y, Williams L, et al. Suppression of autophagy by FIP200 deletion leads to osteopenia in mice through the inhibition of osteoblast terminal differentiation. $\mathrm{J}$ Bone Miner Res. 2013; 28:2414-30. [PubMed: 23633228]

43. Onal M, Piemontese M, Xiong J, Wang Y, Han L, Ye S, et al. Suppression of autophagy in osteocytes mimics skeletal aging. J Biol Chem. 2013; 288:17432-40. [PubMed: 23645674]

44. Willey JS, Lloyd SA, Nelson GA, Bateman TA. Ionizing Radiation and Bone Loss: Space Exploration and Clinical Therapy Applications. Clin Rev Bone Miner Metab. 2011; 9:54-62. [PubMed: 22826690]

45. Lloyd SA, Bandstra ER, Willey JS, Riffle SE, Tirado-Lee L, Nelson GA, et al. Effect of proton irradiation followed by hindlimb unloading on bone in mature mice: a model of long-duration spaceflight. Bone. 2012; 51:756-64. [PubMed: 22789684]

46. Hou J, Han ZP, Jing YY, Yang X, Zhang SS, Sun K, et al. Autophagy prevents irradiation injury and maintains stemness through decreasing ROS generation in mesenchymal stem cells. Cell Death Dis. 2013; 4:e844. [PubMed: 24113178] 
(A)

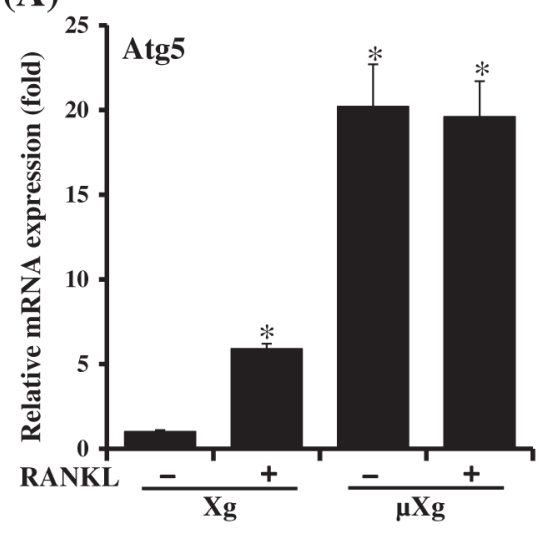

(B)

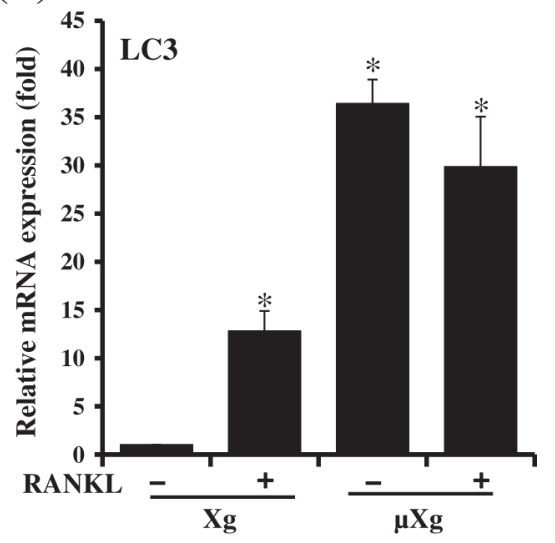

(C)

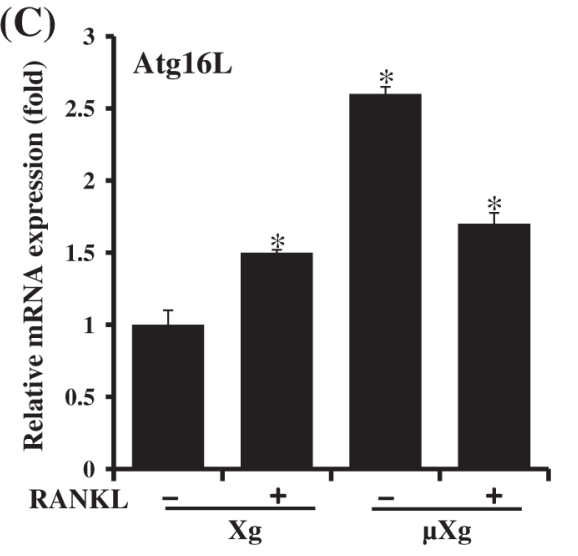

Fig. 1.

Real-time RT-PCR analysis of autophagy marker Atg5, LC3 and Atg16L mRNA expression. Ground based control $(\mathrm{Xg})$ and microgravity $(\mu \mathrm{Xg})$ subjected mouse bone marrow non-adherent cells were treated with or without RANKL $(75 \mathrm{ng} / \mathrm{ml})$ for $24 \mathrm{~h}$. Total RNA isolated were subjected to real-time RT-PCR analysis using gene specific primers for (A) Atg5, (B) LC3 and (C) Atg16L. The mRNA expression was normalized with respect to GAPDH amplification. Each bar represents the mean \pm SD of three independent experiments. *Significant $(\mathrm{P}<0.05)$ difference when compared to ground based control without RANKL treatment. 


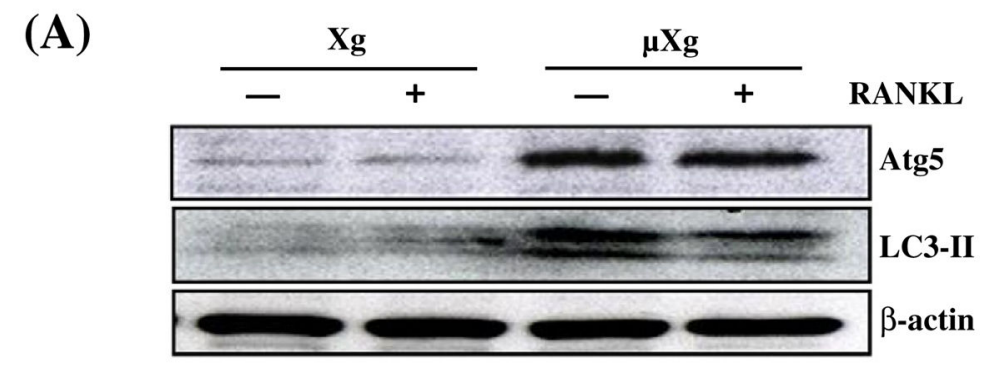

(B) $\mathbf{X g}$
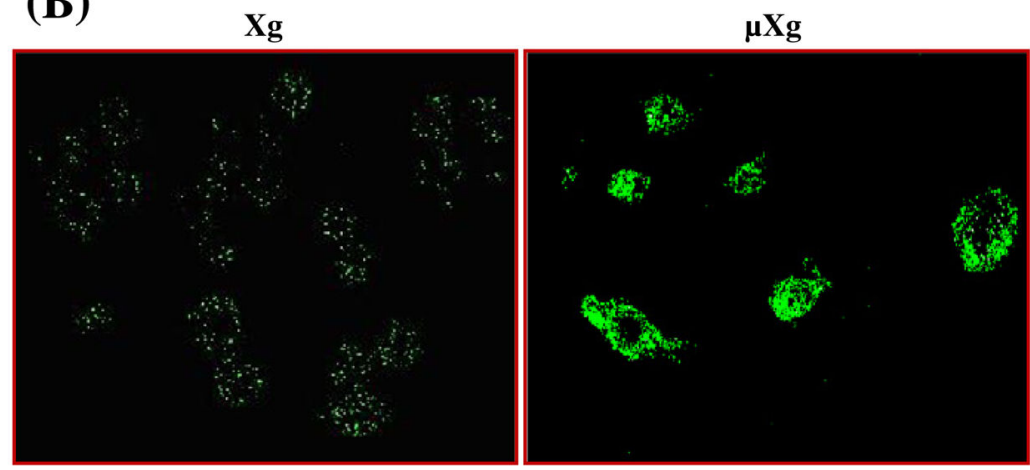

Fig. 2.

$\mu \mathrm{Xg}$ modulation of autophagosome formation. (A) Western blot analysis of Atg5 and LC3-II expression. Ground based control $(\mathrm{Xg})$ and $\mu \mathrm{Xg}$ subjected mouse bone marrow nonadherent cells were treated with or without RANKL $(75 \mathrm{ng} / \mathrm{ml})$ for $24 \mathrm{~h}$. Total cell lysates were subjected to Western blot for Atg5 and LC3-II. $\beta$-actin expression served as control. (B) Autophagosome formation in preosteoclast cells. RAW 264.7 cells were cultured in Xg and $\mu \mathrm{Xg}$ conditions for $24 \mathrm{~h}$ and autophagosomes were visualized by confocal microscopy analysis using anti-LC3-II antibody. 


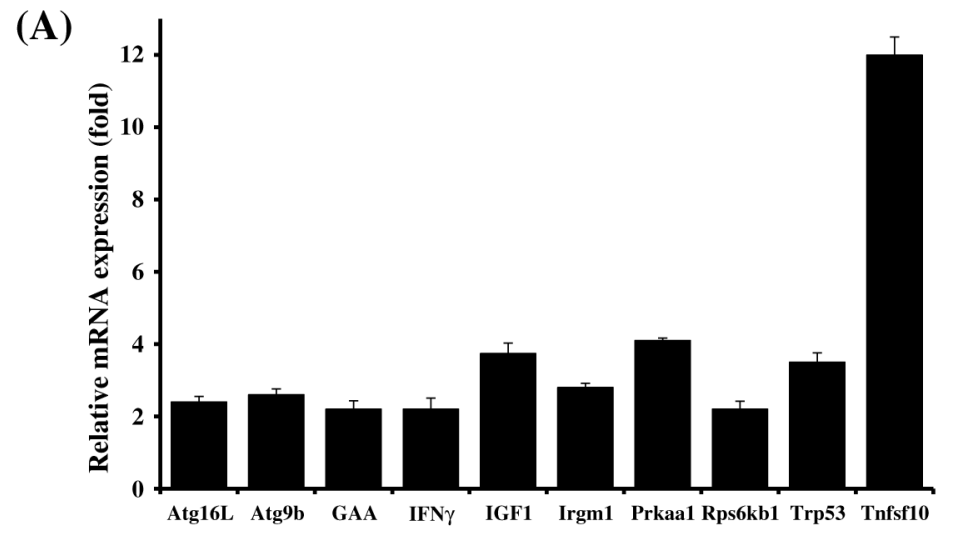

(B)

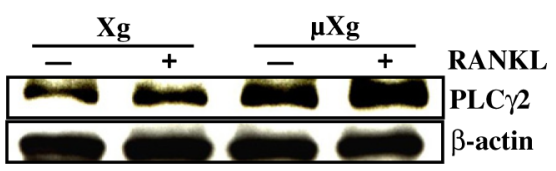

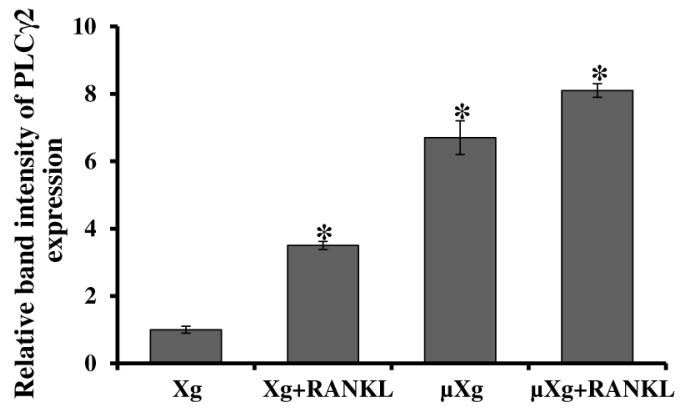

Fig. 3.

(A) $\mathrm{RT}^{2}$ Profiler PCR array analysis for autophagy related gene expression. RAW 264.7 cells were cultured in Xg and $\mu \mathrm{Xg}$ conditions for $24 \mathrm{~h}$. Total RNA isolated from these cells was screened for autophagy related genes by real-time PCR in triplicate studies as described in the Materials and methods section. (B) PLC $\gamma 2$ expression in mouse bone marrow derived non-adherent cells under $\mu \mathrm{Xg}$ conditions. Cells were cultured in $\mu \mathrm{Xg}$ for $24 \mathrm{~h}$ and stimulated with or without RANKL ( $75 \mathrm{ng} / \mathrm{ml})$ for $24 \mathrm{~h}$. Total cell lysates were subjected to western blot analysis using anti-PLC $\gamma 2$ antibody. $\beta$-actin expression served as control. The band intensity was quantified by the National Institutes of Health ImageJ program, and PLC $\gamma 2$ expression was normalized with $\beta$-actin expression in these cells. The values are expressed as mean $\pm \mathrm{SD}$ for three independent experiments. *Significant $(\mathrm{P}<0.05)$ difference when compared to ground based control without RANKL treatment. 
(A)

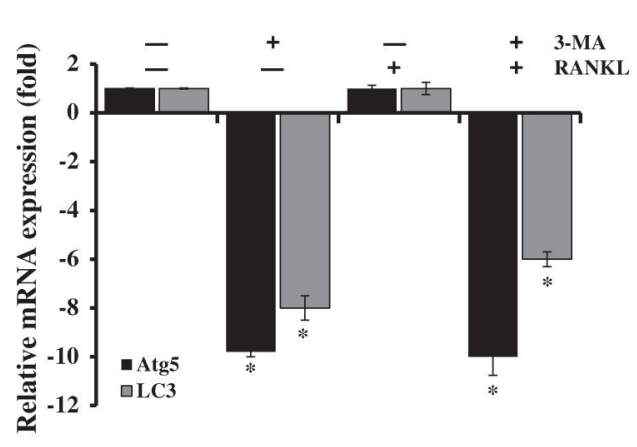

(C)

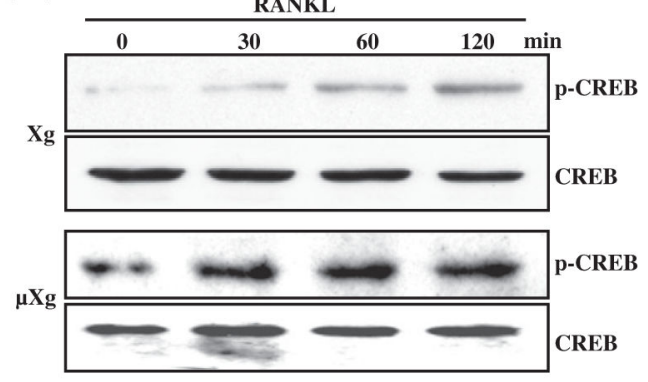

(B)

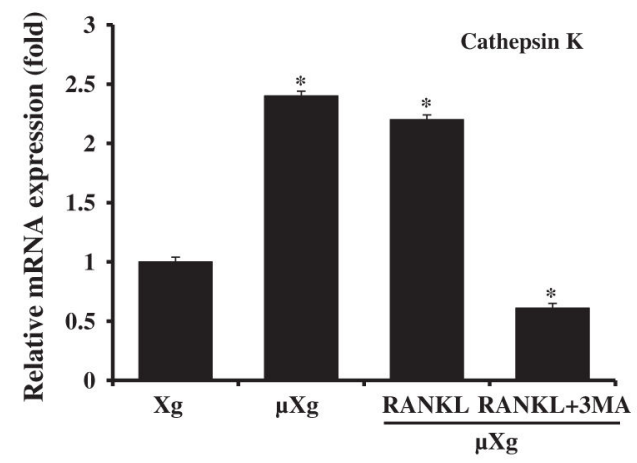

(D)

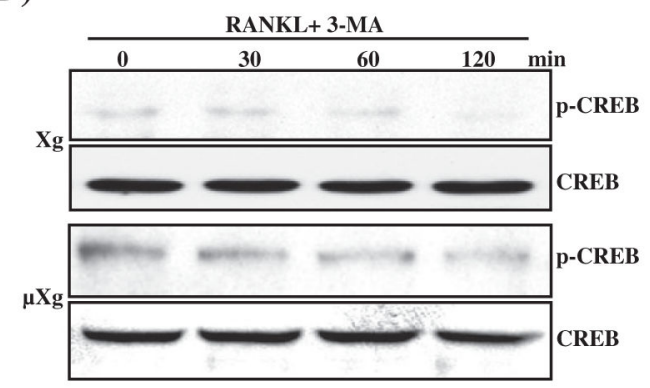

Fig. 4.

(A) Autophagy inhibitor 3-methyladenine (3-MA) suppresses Atg5 and LC3 expression. Mouse non-adherent bone marrow cells were cultured in $\mu \mathrm{Xg}$ for $24 \mathrm{~h}$ and treated with or without RANKL (75 ng/ml) and 3-MA (2 mM) for $24 \mathrm{~h}$. Total RNA isolated were subjected to real-time RT-PCR analysis using gene specific primers for (A) Atg5 and LC3. (B) Cathepsin $\mathrm{K}$ gene expression. mRNA expression was normalized with respect to $\beta$-actin amplification. Each bar represents the mean \pm SD of three independent experiments. *Significant $(\mathrm{P}<0.05)$ difference when compared to ground based control without RANKL treatment. (C \& D) RANKL stimulation and 3-MA inhibition of CREB activation under Xg and $\mu \mathrm{Xg}$ conditions. Mouse non-adherent bone marrow cells were cultured in $\mu \mathrm{Xg}$ for $24 \mathrm{~h}$ and treated with RANKL $(75 \mathrm{ng} / \mathrm{ml})$ in the presence and absence of 3-MA (2 mM) for different time points (0-120 min). Total cell lysate obtained from these samples was subjected to western blot analysis for $\mathrm{p}$-CREB expression. Total CREB expression served as control. 

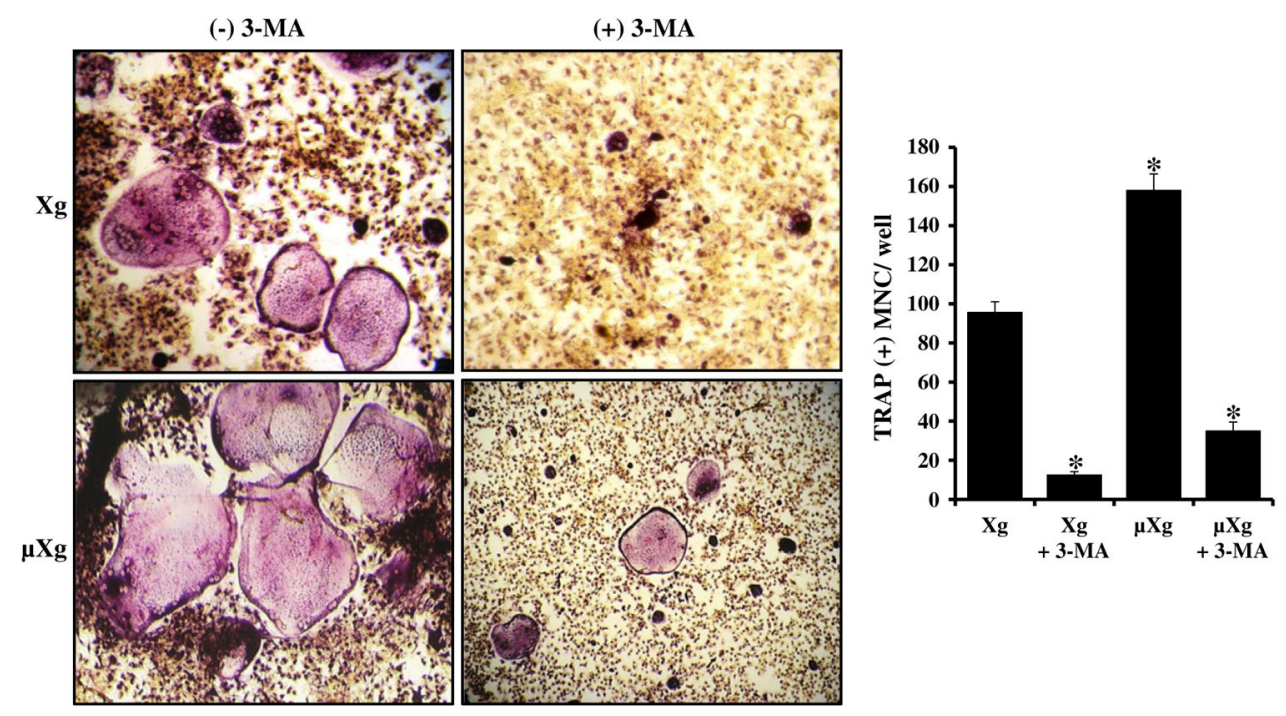

Fig. 5.

Autophagy inhibitor (3-MA) inhibits $\mu \mathrm{Xg}$ elevated OCL formation. Mouse bone marrow derived non-adherent cells were cultured with RANKL (75 ng/ml) and M-CSF (10 ng/ml) for 7 days in the presence and absence of 3-MA $(2 \mathrm{mM})$ under Xg and $\mu \mathrm{Xg}$ conditions. TRAP-positive multinucleated osteoclasts formed at the end of the culture period were scored. *Significant $(\mathrm{P}<0.05)$ difference when compared to ground based control. 